\title{
明治期浜松の内田医院庭園の築庭に関する研究
}

\section{A Study on the Construction of the Uchida Clinic Gardens in Hamamatsu City During the Meiji Period}

\author{
鈴木 里佳* 三浦 彩子** \\ Rika SUZUKI Ayako MIURA
}

\begin{abstract}
Teiji Uchida, a doctor in Hamamatsu City during the Meiji period wrote volumes of diary named "Meiji-nenchuzatsuroku," which includes concrete explanations and records about the construction of his own garden. The construction of the garden started in Meiji 20th and nearly completed in 24th. The majority of the garden plants were purchased in the neighborhood. Noticeably, the cherry trees were transplanted from the neighboring private garden. The record about the engaged people and pay proves the situation of the apprenticeship in gardening business at the time. The research on a gardener Niwahei that took a leading part in construction, his other garden projects, and the comparison between the other gardens of doctors' offices in the district clarified the cultural character of the gardens in Hamamatsu in the middle of the Meiji period.
\end{abstract}

Keywords: Japanese garden, Meiji period, Hamamatsu city, Gardener, Cherry tree キーワード：和風庭園, 明治時代, 浜松市, 庭師, 桜樹

\section{1.はじめに}

近代和風庭園の研究は, これまでに政治家や実業家, 画家, 文 人らの所有した京都や東京の邸宅, 別荘庭園を中心に, その庭園 観や築庭の工程について，一定の知見が蓄積されてきた ${ }^{1)}$ 。一方， 庭園の維持管理については, 具体的な論証資料が不足しているた め, 庭園の普請に関与した庭師名や報酬, 庭園材料の仕入過程, 管理や利用形態の詳細について, とりわけ地方における個人庭園 の築庭の実態や，庭師の活動に関しては未だ不明な点が多い。

本論文で対象とする内田家は, 江戸時代から続く医家の家系と して知られ, 明治時代に静岡県浜松市新町に医院を開業している。 内田家に関する史料は, 当主である内田貞二 ${ }^{2)}$ が長年書き記した 『明治年中雜録』が現存し, 明治中頃に行った建物や庭園の普請 が記録されている。とりわけ庭園関連の内容には，造園工事及び 維持管理を含み, 庭師の名前や報酬, 植木などの仕入先を具体的 に記録した総括的な作業の覚書であることから, 内田医院庭園の 築庭工程を把握するための重要な手がかりとなる。一方, 絵図史 料としては明治 25 年（1892）刊行の『静岡県明治銅版画風景

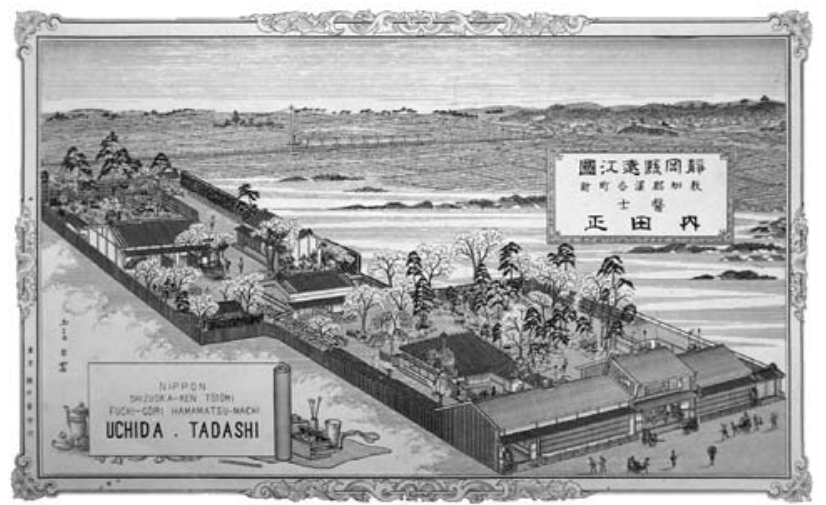

図-1 内田正邸 (『静岡県明治銅版画風景集』より抜粋)
集』に収録された「静岡県遠江国 敷知郡浜松町新 医師内田 正」と題した銅版画がある。東海道側を正面とした細長い敷地内 には，通り側に建設された診察所などの計 8 棟の建物の他，桜樹 を多く配植させた庭園が鳥瞰図風に精密に描写されている（図一 $1)$ 。

本論文では，『明治年中雜録』の翻刻文を銅版画の特徴之対照 し, 内田医院内に作られた「西庭」「園中」「隠居庭」の 3 つの工 リアの築庭工程を分析する。これにより，地方の名士による作庭 趣味及び, 樹木に関する流通の実態, 管理の頻度など, 浜松地方 における近代和風庭園の作庭内容の特徵を解明するものである。

\section{2.『明治年中雜録』について}

『明治年中雜録』は，浜松市立中央図書館に所蔵され，冊数は， 『明治年中雜録 壹』から『明治年中雜録 拾肆』までの 14 冊か ら成り, 記載時期は明治 14 年 8 月 31 日から明治 32 年 2 月 26 日 までの約 18 年間にわたる。寸法は縦 $34.0 \times$ 横 $12.6 \mathrm{~cm}$ の和装本 で，美濃判和紙を横に細長く二ッ折りにし， 1 冊につき約 60 枚 が綴じられている。保存状況は, 一部, 虫損の著しい箇所がある ものの全体的に良好であるが，『明治年中雜録 拾参』を欠失し ている (図-2)。既往研究では, 診客録や医師会の議事録など, 主に医院業務に関する内容が紹介されている ${ }^{4)}$ 。

\section{（1）内田医院の造園工事の過程}

『明治年中雜録』の原文は，例として第 1 巻目の明治 15 年 5 月の項目に「庭作平兵衛 五月八日壱工 三拾銭卜飯酒 櫻起コ シ細葉刈込等」と表記されるように, 庭師や大工, 左官職人など の職人名や，施工日時と内容，報酬金額の詳細が判明する。『明 治年中雜録』に記載された庭園の普請について年表に整理したも のが，[表－1］（内田医院造園工事年表（明治 14 年～明治 24 年) と [表-2]（内田医院造園工事年表（明治 25 年〜明治 31 年))である。工事の項目を，「施工」「維持管理」「調達」と「庭 師」の大項目で区別し，大項目をさらに作業種毎の小区分に分類

*名城大学大学院理工学研究科 **名城大学理工学部建築学科 


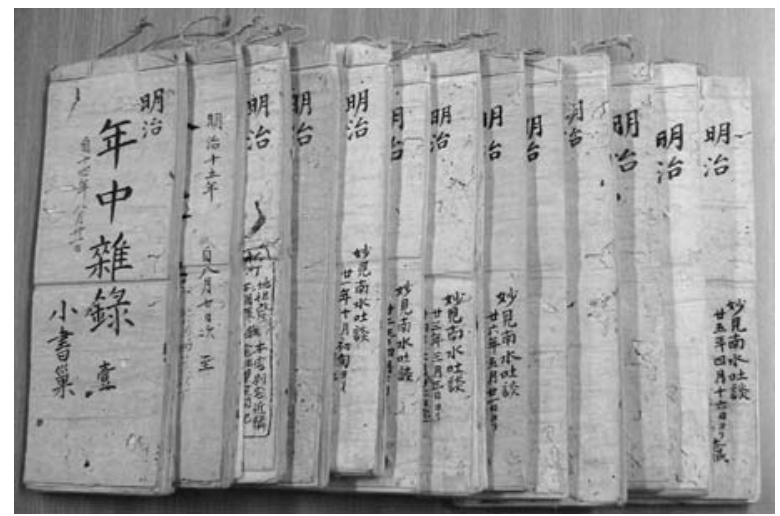

図－２『明治年中雜録』表紙（写真左より壹巻）

して, 日付と作業の内容を原文から抜粋して年代順に表を作成し， 工事の経緯を示した。屋敷地内には図－3に示したように「西庭」 「園中」「隠居庭」の 3 箇所に庭園が存在したことが, 銅版画から も確認されるが，原文から施工位置が明らかなものについては， 表に記載した【月日】の冒頭に，それぞれ別の記号（○一西庭 $\triangle$ 一園中 ○一隠居庭）を付記して, 施工位置を区別している。

一方, 建物の普請の流れを概観すると, 明治 15 年から明治 16 年に行なわれた, 建物全般に及ぶ軽微な修繥と, 「診察所」の素建 を主とした〔第 1 期工事〕をして, 明治 22 年から明治 24 年の, 「園亭」や「隠居」の新築を行なった〔第 2 期工事〕では, 建築工事 に先駆けて, 明治 20 年 12 月から「園亭」近くの「西庭」の造園が始 まり, 明治 21 年 12 月に築山の改修, 明治 22 年 3 月頃からは「園 中」付近の造園にも着手し, 明治 22 年 6 月にかけて植栽を主とし た庭園の骨格がほぼ完成した。さらに, それ以降に行なわれた 「園亭」の増築や「土蔵」の修復, 「上雪院」聚遠楼」の屋根葺替といっ た〔第 3 期工事〕の，3期にわたって建築工事が行われている。

明治 23 年の 3 月頃から「隠居庭」の本格的な工事が始まり, 明 治 24 年 6 月頃までに銅版画に見られる庭園形態に至った。「隠居 庭」は, 外露地之内露地を造り, 3 基の石燈篭を置いた茶庭風の 意匠が見られ, 実際の利用形態については, 『明治年中雜録』に 「西庭」で春の花宴を催した様子や, 後に家督を継ぐ内田正の浜松 町長就任時期の, 地元の名士を招いた秋の花宴などが記録されて いる。
築庭工程については，樹木の植付けや移植の時期は，主に 2 月 から春先にかけ高木の桜樹や楓が植樹されており，山採りの時期 は, 松は 3 月下旬から 4 月, 躑躅や苔, 草物は 3 月から 5 月にか けてみられる。維持管理の実態については，1月下旬から 2 月上 旬に肥料を入れ，4 月から 9 月にかけて，松や柳，菊などの剪定 之細葉 ${ }^{5)}$ の刈込みを行い，虫の駆除は 7 月下旬に集中して行なわ れるなど，毎年定期的に庭園の管理が行われた過程が [表 -1 ，

\section{2]より読み取れる。}

\section{（2）植木の仕入と価格}

銅版画にも多く描かれている桜樹や松などの，庭園の主景とな る植木は, 主に近隣の私邸庭園から購入されている。明治 20 年 の大松の運搬は, 13 人を要する大掛かりなもので ${ }^{6}$, 価格は, 同 時に購入した松と合わせ 2 本で 125 銭であった。その他に小松や 苔, 躑躅などは, 数人の庭師が近隣の山から採取して, 庭に移植 した経緯が記録されている77。桜樹の購入に際しては詳しい記録 が残っており, 明治 18 年と, 20 年から 23 年の 4 年間, さらに 明治 26 年にかけて, 施主の貞二が庭師の番頭である平兵衛（庭 平）を伴って踏査を行なっていた様子が分かる ${ }^{8)}$ 。踏査記録には， 「鴨江」「富塚」「元目」といった地名が，桜の呼称に使われる特 徵があり, 樹形は「元目八高二間以内一根二本立三尺許上二テ四 本トナリ廣ガル因テ樹形高カラズ」などと表記されている。これ らの踏查により園内に植樹する桜樹が決定し, 庭平とその妻が植 木購入の仲介を行なっている ${ }^{9)}$ 。桜樹の購入に関して，例えば明 治 20 年 12 月 7 日の原文に「元目櫻價七拾銭 幸内櫻價五拾銭

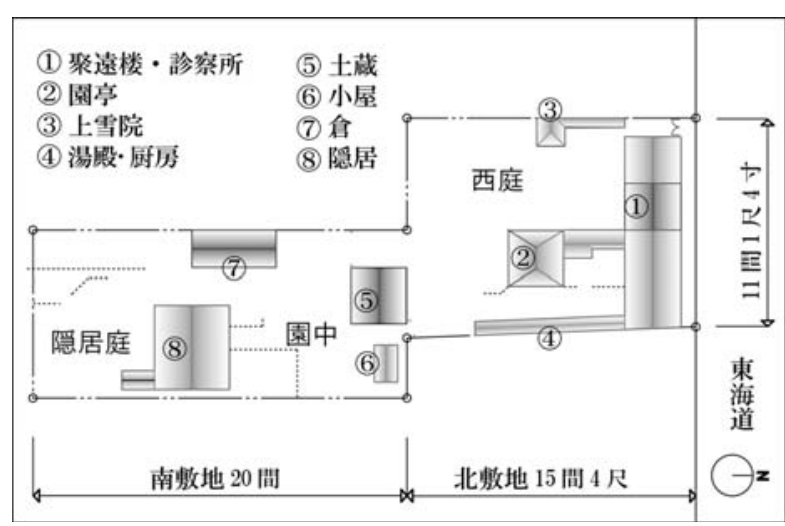

図 -3 屋敷見取図

表 -1 内田医院造園工事年表（明治 14 年 明治 24 年）

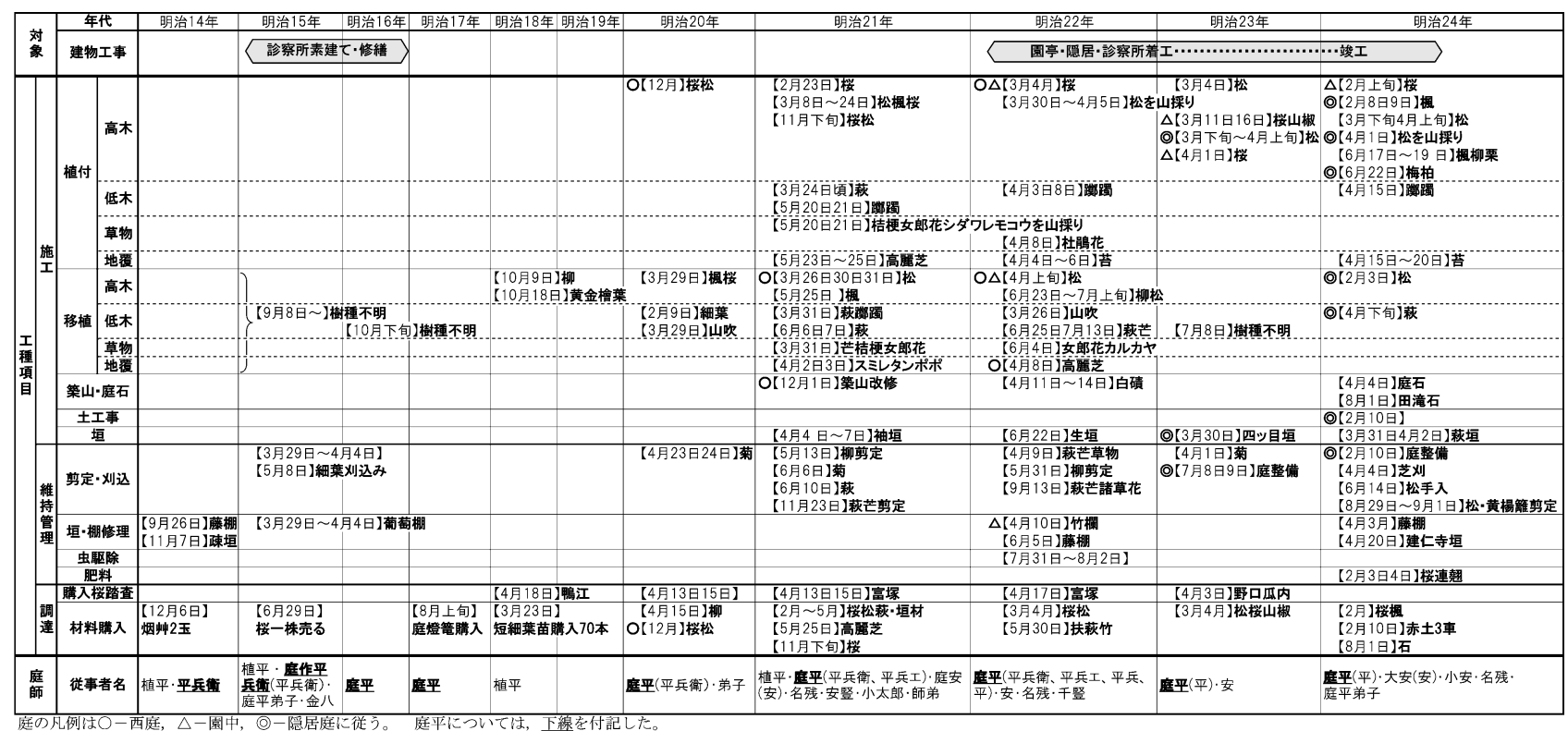


先ヅ南屏九日頃」とあり, 仕入先 (元目町 - 幸内氏), 植物名 (桜), 価格 (七拾銭・五拾銭), 庭園の植樹位置（南塀）が記録 されている。こうした桜樹の購入地は, 内田家からおよそ半径 2 キ口圈内にある近隣の個人宅に集中する傾向がみられ，明治 20 年から明治 24 年までの期間に, 計 18 本の桜が植樹されている。 桜樹の価格については, 最高で 70 銭と記録にあり, 平均して価 格は 43 銭程度である。

\section{3. 内田家に関与した庭師}

明治 14 年から明治 31 年までの期間に, 『明治年中雜録』に記 載された庭師の名前を, 原文の表記に従って掲載したのが $[$ 表一 $1,2]$ 下段「庭師」の項目である。明治 14 年 9 月 26 日の原文 には「植平傭金両人来り柳傾 $ᄏ$ 正シ藤棚 7 整へ諸樹ノ傾 とあり, 植平という人物が藤棚の整備を行い, 明治 15 年 6 月 29 日の原文の「櫻壱株植平ノ媒 $\ni$ 以テ錺琴二賣ル」から, 桜樹の売買 の仲介を行なった様子が分かり, これらの記録から,「植平」と は樹木関係の専門業者であると推測される。

「庭平」は，記録に見える庭師名では最も多く確認される ${ }^{10)}$ 。 浜松地方における庭師の系譜については，これまでほとんど解明 されておらず「庭平」の名も初出である。明治 22 年春の記録に は「庭平及安廿武年」といった見出しが付記され, 以後数ヶ月間に わたり日付順に列記した形式で, 庭平の造園工事が記録されてい る。例えば「六月廿三日平安二人来諸植換」のように,「平」や「安」 など, 庭師名を簡略して表記されており, とりわけ「平」の記載頻 度が目だって高いことから，「平」が「庭平」と同一人物である 可能性が高い。このように常に造園記録の筆頭に明記される庭平 は, 内田医院の造園工事の専属的庭師であったと推測される。庭 平は, 桜樹の踏査時にも施主に同行し, 植木の売買の交渉に関わ るなど，施主の身近にいて，施主の好みを熟知した庭師であった。

前述した「安」という人物については，明治 21 年 11 月 28 日の 原文に,「助信村漆屋北隣浅紅櫻樹價五拾銭庭平卜名残壱人卜往 キ移来植著日尚高シ此日手分二テ安卜名残二人卜富塚松 移来植 著」とある。庭平と安が，桜と松の植樹を分担した記録であるが， 翌日の記録に「庭平庭安名残一人二テ庭中櫻松数株ノ位置 改么」 とあり,「安」と「庭安」が連日記録されていることから,「庭安」 と「安」は同一人物の可能性がある。明治 24 年の 3 月 31 日には 初出である「小安」の名前が見られるが, それ以後に「安」の記述が
ないことから推測して，新たに「安」の弟子が加わったことで， 「大安」と「小安」の 2 人を区別させた表記に変わったと考えられる。 明治 24 年 6 月 14 日の原文に「庭平大安小安来松手入」とある が, 庭平・大安・小安の 3 人で従事していた記録は他にも多数あ る。その他の庭師名は, [表-1，2] に示すように, 安豎, 千 豎，新豎 (林平)，小豎，清豎 (清太郎)，豎弥（弥太郎）が確認 された。また, 名残と呼ばれる人物が多数従事していたが, 名残 とは, 浜松城より北西にあった地名で, 名残の出身人物には永太 郎や梅吉，草吉が記録されている。

以上の記録から, 庭平と協働する庭師に「庭安」「小安」が挙 げられ，仕事の規模に応じて名残の人物や安豎などの協力を得て, 造園工事が行われていた。報酬金額については，明治 14 年之 15 年の記録が残され，植平と庭平の一日あたりの工賃が，夕飯付き で 30 銭支払われている。弟子についても同じ金額の工賃が設定 され，施主から庭平にまとめて支払われていた ${ }^{11}$ 。内田家に出入 りした大工の一日あたりの工賃が 37 銭 5 厘, 左官職人が 35 銭で あると比較すると，庭師の工賃は大工よりも低い。

『明治年中雜録』には, 内田医院の庭園の他に, 新町の別宅や, 野口村の屋敷庭園と足立家屋敷庭園にも, 庭平が関与した記録が 見られる。足立家以外は全て内田家所有の屋敷であったが，別宅 は医院近くの東海道沿いに位置し, 明治 18 年 3 月 28 日から内田 家の所有となり，規模は間口 2 間 3 尺, 奥行 15 間 5 尺, 総坪数 40 坪あまりの小敷地であった ${ }^{12}$ 。この別宅には楓や芒，熊笹，松， 桜苗を植え, 明治 27 年には庭平が葡萄棚の改修を行なってい $3^{13)}$ 。野口村の屋敷は, 内田貞二の父足立東郊の生家であり，そ の屋敷を貞二が継承した ${ }^{14)}$ 。野口村の屋敷庭園については, 竹刈 を行い, 細葉苗などが植えられた ${ }^{15)}$ 。足立家屋敷庭園は, 貞二の 父足立東郊の孫の足立謙一郎の屋敷である。明治 29 年 10 月 12 日から 14 日まで, 大安と小安と名残が作事に従事しているが备), 明治 30 年 3 月 18 日の大安に関する原文に「鳥居屋大株梅ノ半朽 古木ヨ移スヨ嘱セラレ彼方二往ク此梅八六人擔ヒ二テ小安梅吉外 車夫儀助更二二人大安共六人二テ擔ギ来ルト云フ」や，同年 4 月 30 日の庭平に関する原文「昼庭平チョト顔 7 出シ曰ク今日八白山 下琴師ヨリ足立方へ楓樹ヨ移スト(阿夫佐曰ク楓ノミナラズト)」 により, 庭平や大安, 小安, 名残の梅吉により, 足立家の新庭に 植樹が行なわれた様子が分かる。

庭平は個人の邸宅以外にも, 地元の茶産業の施設内の作庭も手

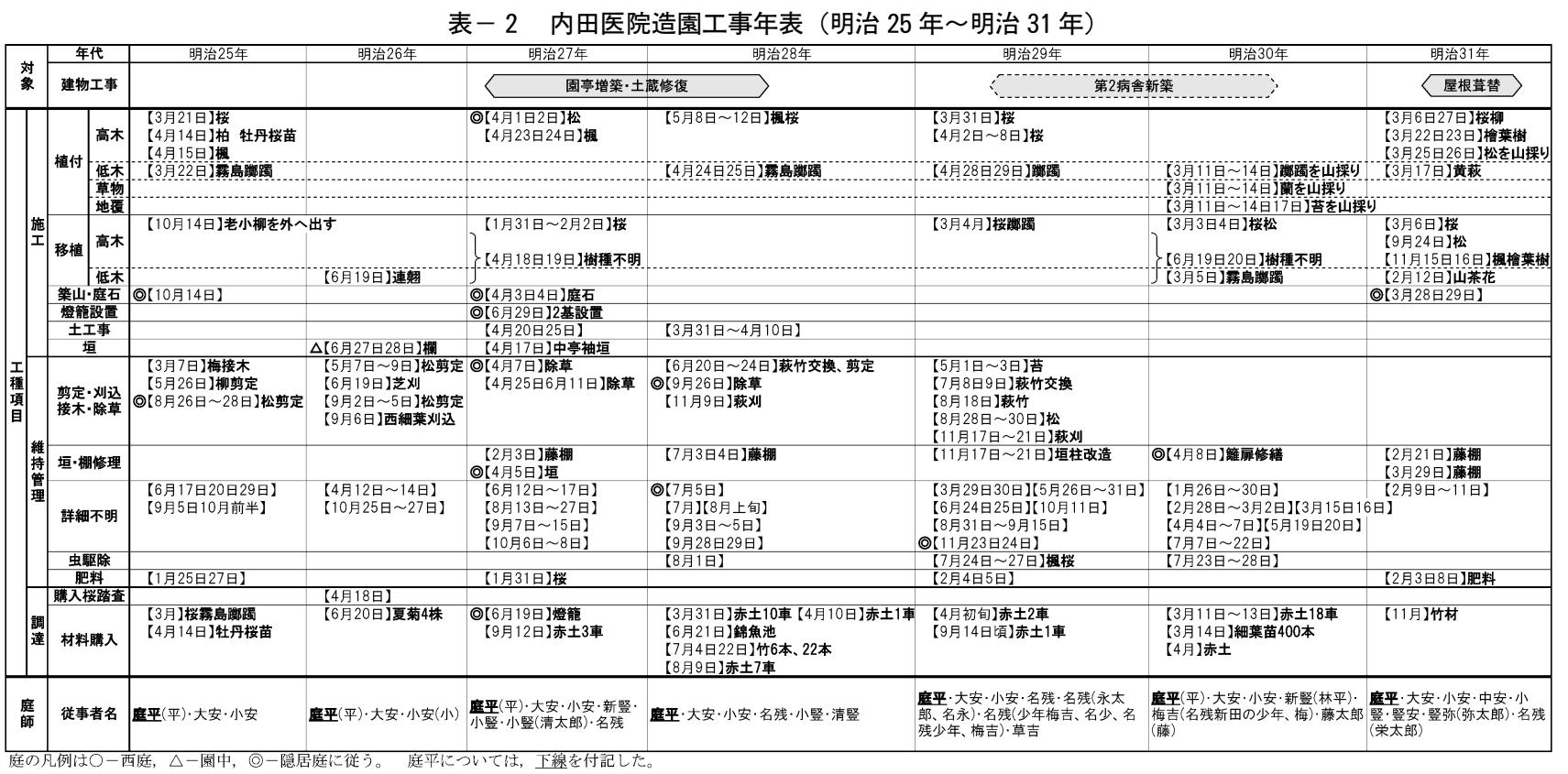


がけている。『明治年中雜録』の第 8 巻目の明治 24 年 9 月 1 日の 原文に「九月一日又三人来以上三個日ニテ松 ヨリ百里園二往ク」の記録がある。原文中の「又三人来」とは, 数 日前の「三十日庭平両安来」の記録から類推して, 庭平と大安, 小 安の三人であるが, 内田家の松の剪定を済ませ, 翌 2 日より「百 里園」に行った内容である。この「百里園」とは, 現在の浜松市三 方原にあった製茶工場で, 明治維新後, 駿府藩の藩士が三方原に 入植し民間と共に茶園の開拓が進められ, 明治 19 年 5 月 27 日に 製茶場新築の落成式が行われ ${ }^{17}$, その様子は銅版画で見る事がで きる（図-4）。明治 45 年に焼失し現存しないが，当時の製茶工 場の規模は, 建物数 20 棟, 建物延坪が 1050 坪であり ${ }^{18)}$, 緑茶や 紅茶，烏龍茶の製造所および，職人の寄宿所が建設された。ロの 字型に建てられた製造所と，その内側には事務所や倉庫，桜樹を 多く植えた中庭が見られる。さらに前面を通る金指街道は, 低木 の桜樹を配列した桜並木道で, 敷地内から街道沿いまで, 桜を主 体とした景観が作られていた。

内田家近隣の, 浜松市中区鍛治町には, 医師福島豊策 ${ }^{19)}$ の医院 之付属の屋敷があり，その様子は銅版画から推察される（図－5）。 福島豊策と内田貞二は, 医会や浜松老年会で交友があり, 2 人が 桜談を交わした記録が，『明治年中雜録』の第 5 巻目の明治 21 年 4 月の原文にも「福島氏櫻花談」と題し,「越永櫻数株 株廿五銭二テ買フ皆尋常品/由四月八日植松村小太郎一株 $\ni$ 媒又 蓋シ楊貴妃ノ類也四月九日幸内中樹 7 庭平媒二テ壱円二買フ」と 記録されている。植木の仕入には, 庭平と小太郎が関与したが, 「小太郎」とは [表一 1 ] の明治 21 年にも登場した庭師であり, 小太郎の仲介により, 福島は品種楊貴妃の桜を購入し, 庭平の仲 介により桜を 1 円で購入している。銅版画には, 出島に懸かる太 鼓橋や，広大な池泉に船を浮かへて釣りをする人物が描かれてい る。

\section{4. まとめ}

以上の『明治年中雜録』の分析によって, 明治中頃の内田医院 庭園の築庭に関与した庭師とその作業の詳細及び，植木の仕入方

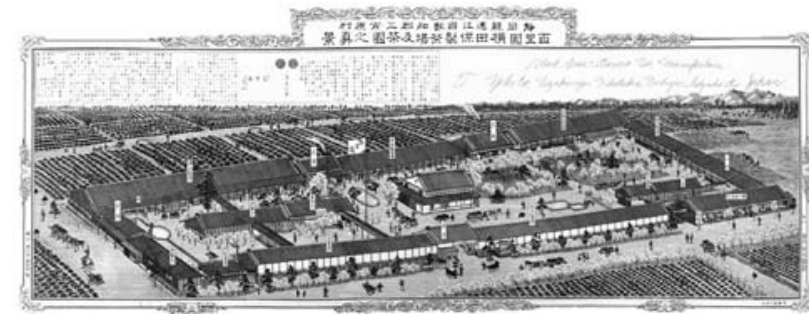

図－４百里園製茶場（『静岡県明治銅版画風景集』より抜粋）

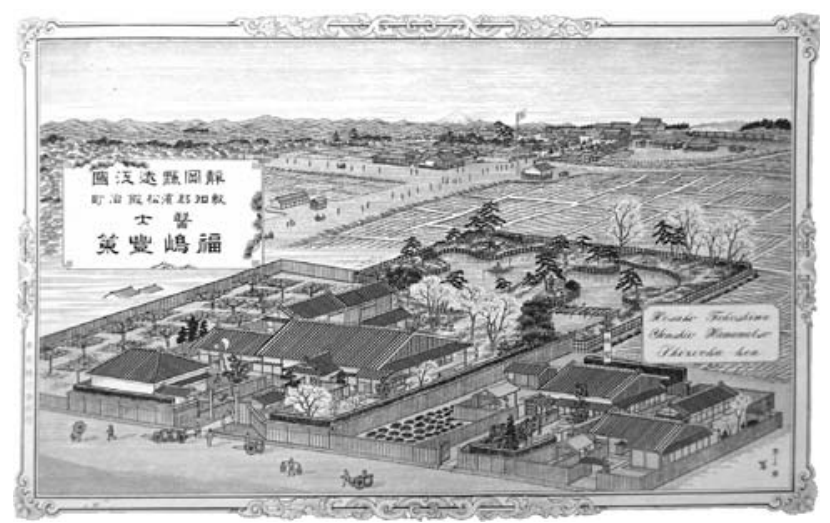

図－５福島豊策邸（『静岡県明治銅版画風景集』より抜粋）
法など浜松地方における庭師の活動の一端が明らかになった。

植木職人の「植平」や,「庭平 (庭作平兵衛)」をはじめとして, 約 16 名の職人の出入りが記録されている。明治 14 年の記録には, 植平と庭平の 2 人の名前があり, 植平が植木の仲介を行なったが, 後年になると明治 21 年の桜の踏査に庭平が赴き仲介にあたるな ど，植平から庭平へと役割が継承されている。明治 21 年の記録 には, 植平と庭平と共に「庭安（大安）」が加わり，その後，庭 平, 庭安 (大安), 小安の師弟の関係にあると思われる庭師が専属 的に従事するなど，徒弟制度の中で技術が継承されていった様子 を窥い知ることができた。庭師が従事した内容は, 庭園の維持管 理の他に, 山野に自生する樹木を掘り取ってくる山採りから, 園 内への搬入, 植付けといった一連の作業が含まれる。庭平は, 内 田家の所有する別宅や野口町の屋敷, 足立謙一郎屋敷の作庭も行 なったが，その他にも製茶工場の「百里園」にも関与がみられ，庭 平は地元の名士や, 企業からも造園を請け負うほどの庭師であっ たことが確認された。当地方の近代和風庭園については, ひきつ づき調査を行ないたい。

\section{補注及び引用文献}

1) 特集（2008）：ランドスケープ研究の動向：ランドスケープ研究 $72(1)$, $9-15$

2 ）土屋重朗 (1973)：静岡県の医史之医家伝：清水市戸田書店, 219-221 に上 れば, 内田貞二は, 安政のコレラ流行期の感染予防書の『防疫貴目』や幕 政の天保の改革に対する政治批判を述べた書物『破地士等巢』の作者であ る。号を乾隈といい, 漢学を学び江戸に出て塩谷岩院にも学び, 岩陰塾の 塾頭となった。また, 蘭学を修め, 当時の眼科の大家土生の門に入り学び 兵松に帰り開業した。

3 ) 若林淳之 (1991) : : 静岡県明治銅版画風景集 : 羽衣出版有限会社, 404 に よれば, 全部で 437 図の銅版画が掲載されており, その内訳は明治 25 年刊 行の『日本博覧図・静岡県・初篇』228図と, 明治 26 年刊行の『日本博覧 図・静岡県・後篇』200䍚( 他に番外 9 図) の合計 437 図である。そのう ち重複掲載された 68 図を除くと, 全部で 369 種類の銅版画が収録されてい

)

東海展望社（1985）：東海展望 6 月号 : 東海展望社, 46-47 に上れば, 近代 医学の育成に大きな貢献をもたらしたとされる, ドイツ人の医学者ベルツ 博士が浜松を訪れた際に，内田家で歓迎した様子が,『明治年中雜録』に記

5)「録されている。細葉」の購入記録は,『明治年中雜録 拾武』明治 30 年 3 月 14 日の原文 「新原村江間平六ヨリ細葉苗来儿四百本價金武円庭平方迄ノ運賃拾銭」とあ り, 兵北地方の新原村より苗を仕入れている。稲永幸男(1982) : 旦本に おける緑化産業の地域的配置に関する研究: 立正大学文学部緑化産業研究

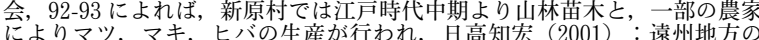

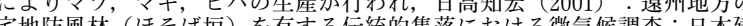
无地防風林(ほそは坦)を有する伝統的集落における微父候調查：日本建 築学会東海支部研究報告集第 39 号, 501-504によれば, 遠州地方には「ほ そば垣(イママ樹種はマキ科のイママ科)」を有する住宅が多く存在するこ

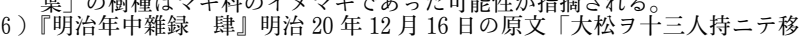
『明治年中稚録㖀』明治 20 年 12 月 16 日の原文大松习十三人持二テ移 シ場二据へ立テ置ク大松卜南屏松卜二本二テ價壱円廿五銭」による。

7 ）『明治年中雜録陸』明治 22 年 3 月 30 日の原文「朝ヨリ庭平等二人政吉及 名残一夫卜往キ赤松五株 $三$ 車二載セ山ヨリ移シ来リシ時日没頃也一株八 薄暮四株八夜二入リ植ユ五株價四拾銭」のほか, 類似する記述による。

8 ）『明治年中雜録 伍』明治 21 年 4 月 13 日の原文「平兵衛小太郎安三人ノ庭 エ及ビ武田生 ヨ携へ池川二至リ池川氏櫻 ヨ觀ル (後略)」による

9 )『明治年中雜録伍』明治 21 年 4 月 15 日の富塚太平所有山の桜の原文「此 日平兵衛妻太平二至り此樹)謀談 $ナ$ (以下略)」とある。また, 小犁村 字平道傍名花の原文 $「$ (前略) 平兵曰く此持主八我ガ識ル人也談ジ易シト」に

10）『明治年中雜録 壹』明治 14 年 11 月 7 日の原文「中坪疎籬十一月七日午后 ヨリ平兵衛来リ (以下略)」とあり, 明治 15 年 5 月 8 日の原文「庭作平兵衛 五月八分壱工三拾銭卜飯酒櫻起コシ細葉刈込等」とある。明治 16 年の原文 「庭平十月下旬三筒日来此時移捙等ヨナス」と庭平名が見られる。

11）『明治年中雜録 壹』明治 15 年 4 月 4 日頃の原文「此庭平下弟工兵 金式 円拾銭（中略）四月四日庭平エ渡夕ス」による。

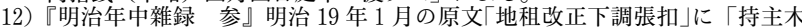
村質文 貞二曰ク明治十八年三月廿八日ヨリ持主内田正九番之内字北側」に 上る。

13）『明治年中雜録 陸』明治 22 年 5 月 8 日の原文「両人来少午前雑事午后雄 松 $コ$ 山ヨリ別宅二移ス」と,『明治年中雜録 拾』明治 27 年 2 月 4 日の原文 「四日同二人別宅葡萄架ヨ改ム」などによる。

14）前掲書 2$), 219$ 雜録 壹』明治 14 年 11 月 7 日の原文「（前略）午后ヨリ平兵衛来 リ余卜共二野口二往キ竹 $\ni$ 伐ル (中略) 庭中整頓」と, 『明治年中雜録揫』 明治 23 年 1 月 28 日の原文「細葉苗廿三年一月廿八日市(中略)五十本八銭 新原村商物右野口宅二植ヘシム (以下略)」による。

16）『明治年中雜録 拾武』の原文「廿九年十月十二日大小安二人（蓋シ此日八 足立謙家ノ嘱卜云) 十三日小安 (此日モ謙家嘱) 十月十四日小穻名残」に 足立誈。

17）浜松市（2002）：浜松市史新編史料編二：浜松市，647-650

18) 財団法人農村開発企画委員会 (2009) : 三方原用水地区歴史変遷資料作成 業務報告書 : 財団法人農村開発企画委員会, 25

19）矢塚克美・神谷昌志 (1983) : はままつ百話一明治・大正・昭和：静岡新 聞社, 96-97によれば, 1838 年佐賀の士族の生まれであるが, 家が貵しく 苦学して医之蘭学を学ぶ。明治 12 年に浜松病院長となるが, 明治 20 年に 辞職し, 浜松宿鍛治町に医院を開業する。山葉寅楠のオルガンづくりを支 援し, また, 毎月自宅にて幻灯会を開き, 衛生思想の啓発のため通俗衛生 講話を催した。 